International Journal of Current Advanced Research

ISSN: O: 2319-6475, ISSN: P: 2319 - 6505, Impact Factor: SJIF: 5.995

Available Online at www.journalijcar.org

Volume 6; Issue 3; March 2017; Page No. 2376-2383

DOI: http://dx.doi.org/10.24327/ijcar.2017.2383.0013

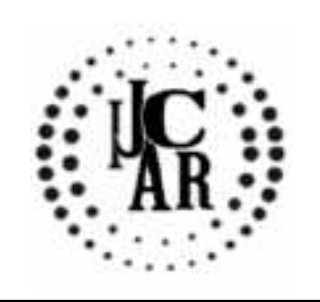

Research Article

\title{
PRODUCTION OF L-ASPARAGINASE FROM RHIZOSPHERE SOIL FUNGUS ASPERGILLUS TAMARI
}

\author{
Mahabal N. S1 and Kaliwal B. B ${ }^{2 *}$ \\ 1Department of Biotechnology and Microbiology, Karnatak University, Dharwad 580003 \\ ${ }^{2}$ Department of Microbiology, Davangere University, Davangere 577002
}

\section{A R T I C L E I N F O \\ Article History: \\ Received $15^{\text {th }}$ December, 2016 \\ Received in revised form $24^{\text {th }}$ January, 2017 \\ Accepted $12^{\text {th }}$ February, 2017 \\ Published online $28^{\text {th }}$ March, 2017}

\section{Key words:}

L-asparaginase, Aspergillus tamarii BBKNM3 strain, Solid state fermentation, Rice bran,

Enzyme activity.

\begin{abstract}
A B S T R A C T
L-asparaginase (L-asparagine amido hydrolase, E.C.3.5.1.1) as of late has been considered as a promising chemotherapeutic specialist against Acute Lymphoblastic leukemia specifically. Its generation, from the contagious sources is currently been broadly considered. Therapeutic use of L-asparaginase from announced sources is restricted because of the immunological reactions prompting to allergies on long term use, unfavorably susceptible responses, hypersensitivity and occurrences of unconstrained resistance of tumor cells. The present investigation aims at the production of extracellular L-asparaginase from fungal sources isolated from rhizospheric soil. The potent producer of L-asparaginase was characterized as Aspergillus tamarii BBKNM3 based on the morphology and molecular characterization. The optimization of production of Lasparaginase was studied using different agro wastes with isolated fungal strains by solid state fermentation. Isolates grown in the medium supplemented with $1 \% \mathrm{~L}$-asparagine as sole nitrogen source yielded the higher productivity of enzyme after $72 \mathrm{hrs}$ of incubation period, at $37{ }^{\circ} \mathrm{C}$ and $\mathrm{pH} 7$. Additionally, $65 \%$ of initial moisture content, glucose $(0.5 \%$ $\mathrm{w} / \mathrm{v})$ and ammonium sulphate $(0.5 \% \mathrm{w} / \mathrm{v})$ was found to be optimum. The rationale behind studying fungal sources is that they are potential sources of novel drugs. Besides, nonimmunogenicity is the added advantage of fungal L-asparaginase over Bacterial Lasparaginase. Hence the present investigation aims at the isolation and characterization of potent fungal producers of L-asparaginase.
\end{abstract}

Copyright $₫ 2017$ Mahabal N. S et al This is an open access article distributed under the Creative Commons Attribution License, which permits unrestricted use, distribution, and reproduction in any medium, provided the original work is properly cited.

\section{INTRODUCTION}

L- Asparaginase has been considered as one of the most potent anti- cancer drugs in the recent decades as it satisfies the requirement that an anti-neoplastic agent should not cause immuno-suppression and yet should be effective against cancer Miura et al., 1971. L-asparaginase is an extracellular enzyme which was introduced in the therapeutics because it was observed that in the patients suffering with Acute Lymphoblastic Leukemia (ALL) malignant cells are dependent on the concentration of L-asparagine. The reduction in the concentration of asparagine molecules causes starvation of the cancerous cells and hence causes depletion of the cells. However, normal cells remain unaffected as they can synthesize L-asparagine.

L-asparaginase is now been widely used in the treatment of many diseases like Hodgkin's disease, treatment of acute lymphocytic leukemia Pieters et al., 2011mainly in children, acute myelocytic leukemia,

*Corresponding author: Kaliwal B. B

Department of Microbiology, Davangere University, Davangere 577002 acute myelomonocytic leukemia and chronic lymphocytic leukemia, lymphosarcoma treatment and melanosarcoma.

Bacteria, fungi, yeast, actinomycetes and algae have been reported as very efficient producers of 1-asparaginase (Savitri 2003; Verma et al., 2007). It was reported that E. coli LAsparaginase inhibits tumors in mice which paved way for the commercial production of the enzyme (Mashburn and Wriston. 1964). Extraction has been studied in a wide variety of organisms. The properties of prokaryotic L-asparaginase were found in contrast with those of eukaryotic Lasparaginase. Bacterial L-asparaginase caused hypersensitivity with a long term use which leads to anaphylaxis and allergic reactions (Reynolds and Taylor. 1993; Ali. 1994; Sarquis et al., 2004). The ability of fungal sources to produce L-asparaginase was different in solid and liquid state fermentation conditions (Lee. 2005). The most adopted method is the submerged fermentation as it has advantages like minimum contamination, rapid growth and high enzyme yield under controlled conditions over solid state fermentation. Moreover submerged fermentation has its own disadvantages to overcome which solid state methodology is more adopted. Submerged fermentation leads to the 
generation of effluents which ultimately calls for treatment process (El-Bessoumy et al., 2004). Hence in the present study an attempt has been made to produce L-asparaginase from a soil rhizosphere fungus Aspergillus tamarii BBKNM3 followed by which its production optimization is also studied.

\section{MATERIALS AND METHODS}

\section{Soil sample chemicals and media}

The chemicals used in this study were of analytical or laboratory grade.

The soil samples were collected in sterile polythene bags from the rhizospheric regions of plants from Garag, Dharwad district, Karnataka, India $\left(15.5700^{\circ} \mathrm{N}, 74.9296^{\circ} \mathrm{E}\right)$. All the chemicals used were of higher analytical grade. The Media used was modified Czapek Dox agar containing $1 \%$ Lasparagine as sole source of nitrogen (Gulati et al., 1997), Potato Dextrose agar (Himedia) and Sabouraud Dextrose agar (Himedia).

\section{Isolation of L-asparaginase producing fungi}

The isolation of L-asparaginase producing fungi was carried out through Serial dilution of soil samples. A $1 \mathrm{~g}$ of the soil sample was added to $9 \mathrm{ml}$ of sterile saline solution and mixed thoroughly. $1 \mathrm{ml}$ of the suspension was added to next tube containing $9 \mathrm{ml}$ of sterile saline up to 7 dilutions. Further, 100 $\mu \mathrm{l}$ of suspension from the appropriate dilutions like $10^{-2}, 10^{-3}$ and $10^{-4}$ were inoculated on the modified Czapek Dox agar, Potato Dextrose agar and Sabouraud Dextrose agar plates by the spread plate method. All the plates are incubated for 7 days at room temperature. The media which was able to support the luxuriant growth of the fungal strains was used for the further analysis.

\section{Screening of L-asparaginase producing fungi from rapid plate assay}

All the fungal strains were inoculated on themodified Czapekdox agar medium containing different concentrations of phenol red $(0.001 \%$ to $0.009 \%)$ as indicator and Czapekdox agar medium composition replacing the Lasparagine with $\mathrm{NaNO}_{3}$ served as control. All the plates were incubated at $37{ }^{\circ} \mathrm{C}$ for 7 days. The strain giving the maximum color zone formation was chosen for further analysis (Lapmak et al., 2010).

\section{Characterization of $L$ - asparaginase producing strain}

The fungal strain which found to produce higher color zone around the fungal growth was identified based on its morphology, Lacto phenol blue staining (Konemanet al., 1977) and ITS sequencing was done at NFCCI, Pune, India. Genomic DNA from the fungal strain was isolated using ABI BigDye Terminator 3.1 cycle sequencing kit. The ITS region of rDNA was successfully amplified using universal primers ITS4, ITS5 (ITS-4: $5^{1}$ TCCTCCGCTTATTGATATGC $3^{1}$ and ITS-5: $\quad 5^{1}$ GGAAGTAAAAGTCGTAACAAGG3 ${ }^{1}$ ). The sequence obtained from ABI 3100 automated DNA sequencer was used for the BLAST analysis (http://blast.ncbi.nlm. nih.gov/Blast.cgi). Further the identification of the strain was done by the percentage of similarity with the other available organisms in NCBI database. The sequence was used for the multiple/pair wise alignment using CLUSTALW. Further, aligned sequence was used for the construction of phylogenetic tree using the neighbor joining method by bootstrap percentage on the nodes. The sequence data was aligned with publicly available sequences \& analyzed to reach identity (Tamura et al., 2007).

\section{Extraction of cell free culture filtrates for L-asparaginase assay}

The fungal strain was grown on the sterile modified Czapekdox broth containing $1 \% \mathrm{~L}$ - asparagine as sole nitrogen source for at $37{ }^{\circ} \mathrm{C}$. After $72 \mathrm{hrs}$ of incubation the fungal mat produced on the medium was macerated for the better mixing. Further, medium was centrifuged at $10000 \mathrm{x} \mathrm{g}$ for 5 mins and supernatant was used for the analysis.

\section{Direct Nesslerization test for L-asparaginase activity}

The reaction mixture containing $500 \mu \mathrm{l}$ of $0.04 \mathrm{M} \mathrm{L-}$ asparagine, $500 \mu 10.5 \mathrm{M}$ phosphate buffer $(\mathrm{pH} 7.8), 500 \mu \mathrm{l}$ of an enzyme extract and $500 \mu \mathrm{lml}$ distilled water to make the volume $2 \mathrm{ml}$. The tubes were incubated at $30^{\circ} \mathrm{C}$ for $30 \mathrm{mins}$. Later, the enzymatic reaction was stopped with addition 500 $\mu \mathrm{l}$ of $1.5 \mathrm{M}$ trichloroacetic acid (TCA). The blank was prepared by adding enzyme after the addition of TCA. $0.1 \mathrm{ml}$ from the above mixture was taken and added to $3.7 \mathrm{ml}$ of distilled water and to that $0.2 \mathrm{ml}$ of Nessler's reagent was added. After incubating the mixture at $20^{\circ} \mathrm{C}$ for 20 minutes the OD was checked at $450 \mathrm{~nm}$ with Spectrophotometer [Hitachi U 2900] (Imada et al., 1973). The enzyme activity was calculated using the following formula and expressed in International unit.

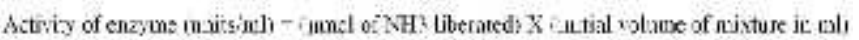

\section{Vol. of enzyme uxixture nsed (Invubution timen 1 vol. of}

engome lesd ir final rin in onl?

Where,

Initial volume of enzyme mixture $(\mathrm{ml})=2.5$,

Volume of enzyme mixture used in final reaction $(\mathrm{ml})=0.1$, Incubation time (minutes) $=30$, Volume of enzyme used $(\mathrm{ml})$ $=1$

One International unit of enzyme is defined as the amount of enzyme needed to liberate one

Micromole of ammonia from L-asparaginase under the conditions of assay $\left(\mathrm{pH}=7.0 ; 37^{\circ} \mathrm{C}\right)$.

\section{Optimization of solid state Fermentation Parameters}

\section{Substrate Selection}

Isolated fungus was grown on various agro wastes like rice bran, rice husk, ground nut oil cake, linseed oil cake, corn kernels and sugarcane bagasse for the screening of substrates for solid state fermentation. $10 \mathrm{~g}$ of the substrate was moistened with water in a $250 \mathrm{ml}$ Erlenmeyer flask and autoclaved. Later, it was inoculated with $1 \mathrm{ml}$ of spore suspension and incubated at $37^{\circ} \mathrm{C}$ for 7 days in a slanting position and the substrates were screened for maximum enzyme production.

\section{Biochemical analysis substrates Estimation of total carbohydrates}

The total carbohydrate content of the substrates was estimated by the method of Dubois et al., (1956) Briefly, all the substrates of $100 \mathrm{mg}$ were mixed with the $5 \mathrm{ml}$ of $2.5 \mathrm{~N} \mathrm{HCl}$ and hydrolyzed in a boiling water bath for $3 \mathrm{hrs}$ and cooled to room temperature. The compositions were neutralized with 
solid sodium carbonate until the effervescence ceases and volume was made up to $100 \mathrm{ml}$ and centrifuged at $5000 \mathrm{x} \mathrm{g}$ for 5 mins. The supernatant was collected and utilized for the carbohydrate estimation with anthrone. The content carbohydrate was calculated with standard calibration curve.

\section{Estimation of total protein}

Extracellular protein content of the substrates was determined by the method of Lowry et al., (1951). Protein samples were mixed with alkaline solution and incubated at $37^{\circ} \mathrm{C}$ for $10 \mathrm{~min}$ and after the incubation time Folin Ciocalteau reagent (FCR) was added and mixed thoroughly with gentle shaking, the concentration of extracellular protein was measured at $660 \mathrm{~nm}$ in spectrophotometer.

\section{Estimation of soluble fats}

All the substrates were grind to make fine powder, $100 \mathrm{~g}$ of each substrate powder wereextracted with $75 \mathrm{ml}$ of petroleum ether in a rotor flash evaporator (Buchirotavapor R 210)and the extract was decanted into small, dry pre weighed beaker and residual ether content was evaporated on heating pan at $30^{\circ} \mathrm{C}$. The difference in the weight of the empty beaker and after evaporation of the ether gives the amount of fat in the sample.

\section{Quantitative assay of L-asparaginase activity}

To extract the crude enzyme from the fermented substrate, $1 \mathrm{~g}$ of the substrate is aseptically collected and mixed with methanol in the ratio 1:10 (W/V). The suspension was gently mixed and filtered using Whatmann filter paper No 1 . The filtrate was centrifuged at $10000 \mathrm{x}$ g for 5 mins at $4{ }^{0} \mathrm{Cand}$ obtainedsupernatant serves as the crude enzyme extract. Further, the content of enzyme was estimated by the Direct Nesslerization test.

\section{Effect of physical parameters on L-asparaginase production}

Different ranges of temperature $\left(25,30,35,37,40\right.$ and $\left.45^{\circ} \mathrm{C}\right)$ and $\mathrm{pH}(4,5,6$ and 7$)$ were tested on the enzyme production. The effect of temperature and $\mathrm{pH}$ on the enzyme production was analyzed using most potent the fungal isolate and substrate which was found to be ideal for the production of enzyme.

\section{Initial moisture content}

The effect of initial moisture content on the growth of the isolate was tested using $10 \mathrm{~g}$ of substrate which was moistened with water in the range of $30-70 \%$ and was inoculated with $1 \mathrm{ml}$ of the fungal spore suspension ( 10000 spores) of fungal isolate and was incubated at $37{ }^{\circ} \mathrm{C}$ for $72 \mathrm{hrs}$.

\section{Impact of incubation time on the production of enzyme}

The role of incubation time on the production of Lasparaginase production was studied by using $10 \mathrm{~g}$ substrate in different incubation periods like 24, 36, 48, 60, 72 and 96 hrs.The fermentation was carried out at $37^{\circ} \mathrm{C}$ and other experimental conditions were referred as constant. The optimum period achieved was taken for further experiments.

\section{Effect of Nutritional parameters on L-asparaginase production \\ Carbon source}

To detect the effect of various carbon sources, the substrate was supplemented with $0.25 \%-1.25 \%$ carbon sources such as glucose, sucrose and fructose.The fungal strain was cultivated and the production was assayed by screening the enzyme activity.

\section{Nitrogen source}

The effect of additional inorganic and organic nitrogen source on L-asparaginase production was studied by adding inorganic nitrogen sources like ammonium chloride, ammonium sulphate and ammonium nitrate and organic nitrogen sources such as peptone, yeast extract and beef extract were used in the range of $0.25 \%, 0.5 \%, 0.75 \%, 1.0$ $\%$ and $1.25 \%$ respectively Ameena et al., 2009

\section{Phosphate source}

Various phosphate sources like di-potassium hydrogen phosphate, potassium di-hydrogen phosphate and diammonium hydrogen phosphate were used in the range of $0.25-1.25 \%$ and were supplemented to the substrate and the fermented substrate was extracted and enzyme activity was recorded.

\section{Metal ions}

The effect of various metal ions was recorded by incorporating the substrate with metal ions such as $\mathrm{Mn}^{2+}$, $\mathrm{Zn}^{2+}, \mathrm{Mg}^{2+}$ and $\mathrm{Cu}^{2+}$ at the concentration of $0.01-0.03 \%$ and the flasks were incubated at $37{ }^{\circ} \mathrm{C}$ for $72 \mathrm{hrs}$. After incubation enzyme activity was recorded.

\section{RESULTS AND DISCUSSION}

\section{Isolation and Screening}

In the present study, total of thirty two fungal strains (BBKNM1-32) were isolated from the rhizospheric soil and four strains namely BBKNM3, BBKNM6, BBKNM11 and BBKNM15 showed positive results for rapid plate assay with coloration zone of $1.61 \mathrm{~cm}, 0.8 \mathrm{~cm}, 0.65 \mathrm{~cm}$ and $0.5 \mathrm{~cm}$ respectively.

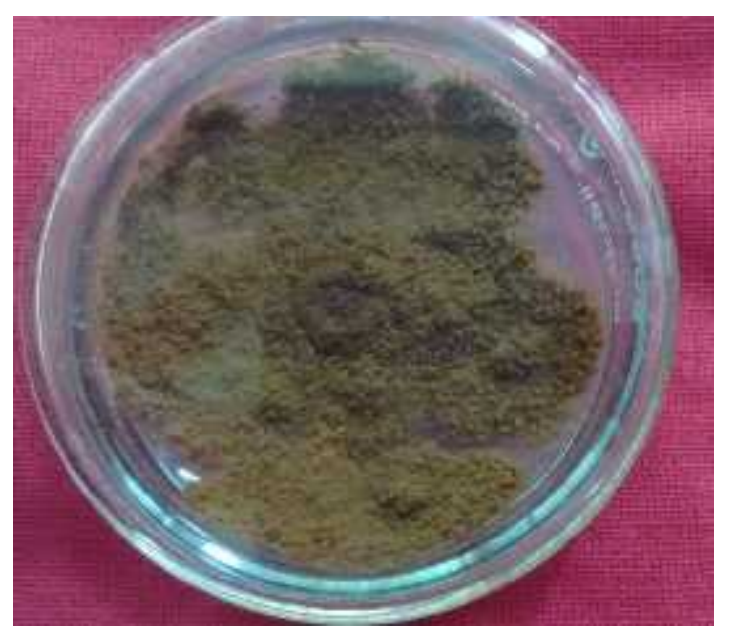

Fig. 1 Aspergillus tamariiBBKNM3 strainon Czapekdox agar plate 


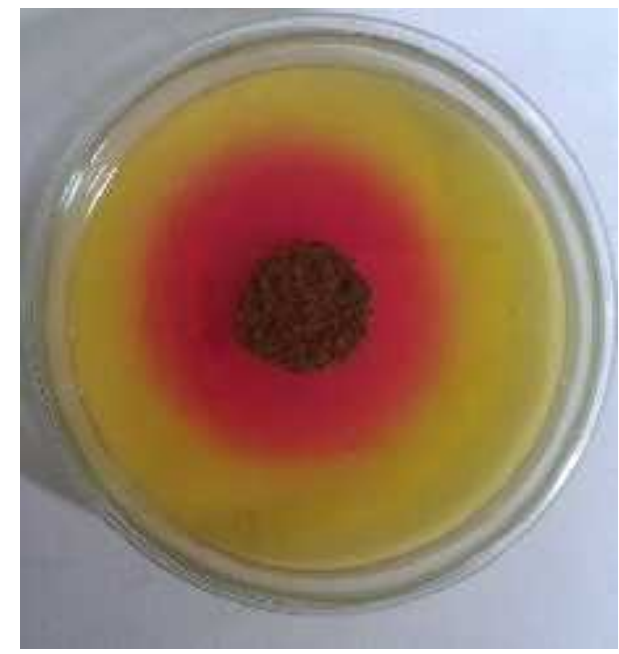

Fig. 2 Aspergillus tamarii BBKNM3 strain showing color zone formation in rapid plate assay

It is also observed that, the strain BBKNM3 (Figure-2) found to be a potent producer of extracellular L-asparaginase with higher coloration zone around its growth.

Soil has been an ideal source for the isolation of microorganisms as it has abundant sources of nutrients. The rhizosphere regions of plants have always been a source of amino acids and root exudates to the growing microflora of the soil (Hosamani and Kaliwal. 2012). Fungi have been reported to be the promising L-asparaginase producers. The first fungal L-asparaginase reported was isolated from Aspergillus terreus and was found to be effective against carsinosarcoma in rat (De-Angeli et al., 1970). The production of L-asparaginase by Aspergillus nidulans was reported and was found non-toxic with immunosuppressive activity (Drainas and Drainas. 1985; Shaffer. 1988)and production of L-asparaginase has been reported over a wide range of fungal sources. The choice of Fungi as the source of the enzyme is due to the fact that prokaryotic L-asparaginase is known to cause hypersensitivity reactions on long term usage unlike the eukaryotic L-asparaginase (Narta et al., 2007). Previously, many researchers have isolated fungi from different samples i.e. Cylindrocarpon obtusisporum isolated from soil(Raha et al., 1990), Aspergillus. terreus isolated from decomposing vegetables (Ali. 1994), Mucor sp. isolated from the marine sponge Spirastrella sp.(Mohapatra et al., 1997), Aspergillus niger (Mishra et al., 2006), endophytic fungi H1BA10, H5BR6 and H5BR7 isolated from Thailand medicinal plants (Theantana et al., 2007), Aspergillus, Penicillum, Fusarium, Helminthosporium, Scophulariopsis, Paecilomyces and Pestalotiopsis isolated from Bhitarkanika mangrove ecosystem (Gupta et al., 2009), Aspergillus sp. (Sreenivasuluet al., 2009b), Bipolaris sp. BR438 (Lapmak et al., 2010) and A. terreus KLS2 was reported to be good source of L-asparaginase(Siddalingeshwara et al., 2010a). Further, modified Czapek-Dox agar was used as a media for the growth of fungi as it showed luxuriant fungal growth (Figure-1). The media contained $L$-asparagine as a sole nitrogen source and phenol red as an indicator. $L$-asparagine also served as an enzyme inducer. The formation of a pink zone around the microorganism was an indication of the $L$ asparaginase production (Figure-2). The color zone formation around the organism is directly related to the ability of the organism to produce L-asparaginase (Lapmak et al., 2010). In our study, the Aspergillus tamarii BBKNM3 strain has shown the maximum color zone formation which directly shows its ability to produce L-asparaginase. The change in color (from yellow to pink) of the indicator resulted from the increase in $\mathrm{pH}$ due to ammonia release. The ammonia along with Laspartic acid is formed by the deamidation reaction of the substrate L-asparagine by L-asparaginase.

\section{Molecular identification}

The fungal strain BBKNM3 was observed morphologically and microscopicallyand was found to belong to the class Aspergillus. The culture showed the presence of visible mycelial growth and microscopic spores. Furthermore, the strain was confirmed at the molecular level by the ITS gene sequencing The strain showed 99\% similarity with a Query Length of 561, Score - 1027 bits (556), Expect - 0.0, Identities - 561/563(99\%) ,Gaps - 2/563(0\%), Strand - Plus/ Minus. The BLAST analysis showed that the strain BBKNM3 was 99\% similar to Aspergillus tamarii strain (122 1 B2).The phylogenetic tree of the same obtained sequence along with the other similar hits was constructed using the MEGA7 software (Figures 3 and 4).

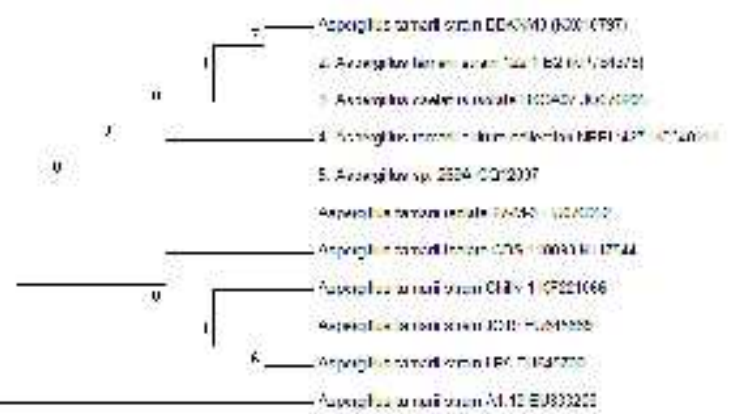

Fig. 3 Phylogenetic tree of LSU of Aspergillus tamarii BBKNM3 strain

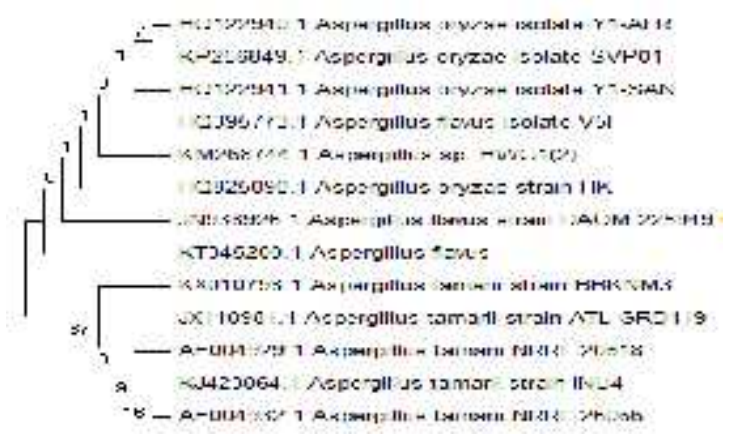

Fig.4 Phylogenetic tree of D1 D2 regions of Aspergillus tamarii BBKNM3 strain

\section{Optimization of fermentation parameters}

Different agro wastes such as rice bran, sugarcane bagasse, linseed oil cake, groundnut oil cake, corn kernels and rice husk were used to determine the best suitable substrate for fermentation. It was found that rice bran gave the maximum enzyme production with $4.32 \mathrm{IU} / \mathrm{ml}$ of enzyme activity (Figure-5). The choice of Solid state fermentation as the suitable method of L-asparaginase production as Solid state fermentation is an effective technique to increase the product yield at low capital cost, low energy requirement, less water output and substrate itself acts as carbon or energy source (Khamna et al., 2009). 


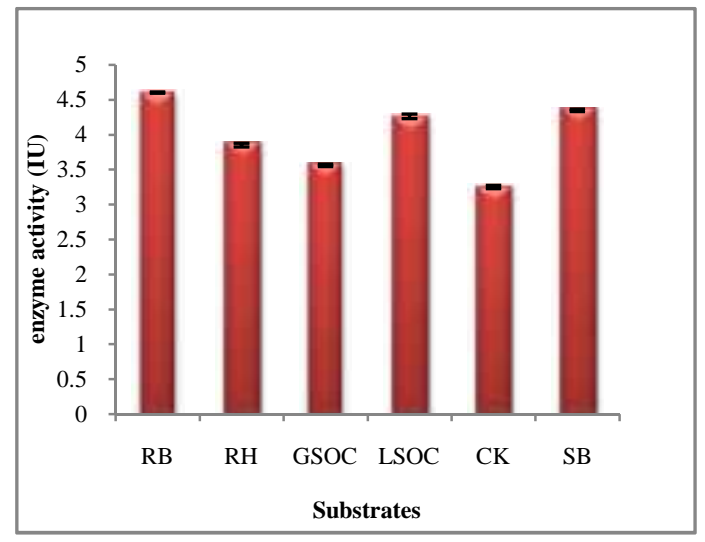

Fig. 5 Effect of various substrates on the activity of Lasparaginase

\section{Effect of physical parameters}

\section{Temperature}

In the present study, Results indicated that L-asparaginase production was observed to be maximum at $37^{\circ} \mathrm{C}$ (Figure-6), followed by $40^{\circ} \mathrm{C}(6.25 \mathrm{IU} / \mathrm{ml}), 35^{\circ} \mathrm{C}(5.60 \mathrm{IU} / \mathrm{ml}), 45^{\circ} \mathrm{C}$ $(5.19 \mathrm{IU} / \mathrm{ml}), 30^{\circ} \mathrm{C}(5.13 \mathrm{IU} / \mathrm{ml})$ and least was found at $25^{\circ}$ $\mathrm{C}(4.78 \mathrm{IU} / \mathrm{ml})$. The higher and lower temperature ranges were altered the metabolic activity of the enzyme (Carrizales and Jaffe 1986). A wide range of temperature stability has been reported by researchers for the production of Lasparaginase. The highest L-asparaginase activity of 40.9 $\mathrm{U} / \mathrm{gds}$ at $30^{\circ} \mathrm{C}$, whereas, optimum activity at $50^{\circ} \mathrm{C}$ (Maladkar et al., 1993). Additionally, thermostable L-asparaginase from Thermusaquaticus was reported, and optimum temperature was found at $75^{\circ} \mathrm{C}$ (Curran et al., 1985).

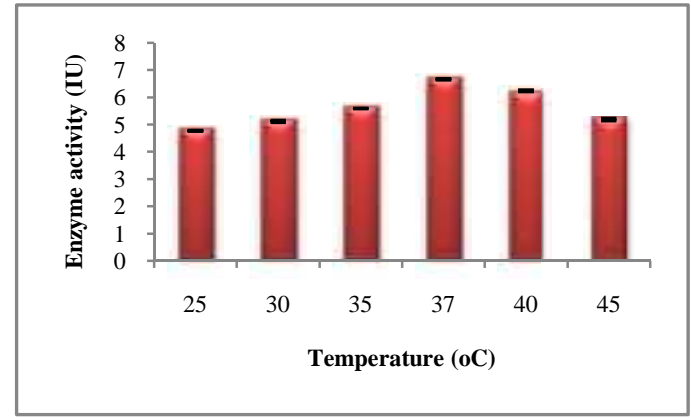

Fig. 6 Effect of temperature on the activity of L-asparaginase

\section{pH}

In fermentation procedure initial $\mathrm{pH}$ plays an important role. The results show that $\mathrm{pH} 7$ was observed to be optimum $\mathrm{pH}$ value for the L-asparaginase production (Figure-7).

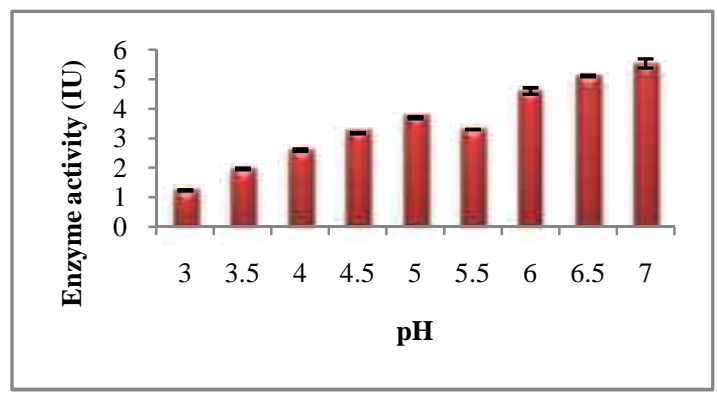

Fig. 7 Effect of $\mathrm{pH}$ on the activity of L-asparaginase
Meanwhile, the production of L-asparaginase was decreased with lower $\mathrm{pH}$ values i.e. $6.5(5.11 \mathrm{IU} / \mathrm{ml}), 6.0(4.60 \mathrm{IU} / \mathrm{ml})$, $5.5(3.30 \mathrm{IU} / \mathrm{ml}), 5.0(3.70 \mathrm{IU} / \mathrm{ml}) 4.5(3.17 \mathrm{IU} / \mathrm{ml}), 4.0$ $(2.60 \mathrm{IU} / \mathrm{ml}), 3.5(1.97 \mathrm{IU} / \mathrm{ml})$ and least with $\mathrm{pH} 3.0(1.24$ $\mathrm{IU} / \mathrm{ml}$ ). Similar results of 7.5 as the optimum $\mathrm{pH}$ have been reported (Narayan et al 2008) [35]. Contradictorily, acidic pH (4.5) was found to be optimum for the higher activity of Lasparaginase (Khamna 2009) [31]. The present result is in agreement with results in which $\mathrm{pH} 7$ had been reported to be the optimum $\mathrm{pH}$ for $\mathrm{L}$-asparaginase production under submerged fermentation (Drainas and Drainas 1985) [21].

\section{Initial moisture}

The results indicated that the moisture content of $65 \%$ gave maximum enzyme activity $(4.08 \mathrm{IU} / \mathrm{ml})$ followed by $60 \%$ (3.72 IU/ ml), $70 \%(3.71 \mathrm{IU} / \mathrm{ml}), 55 \%(3.44 \mathrm{IU} / \mathrm{ml}), 50 \%$ (2.36 IU/ ml), $45 \%$ (2.18 IU/ ml), $40 \%$ (1.25 IU/ ml), $35 \%$ $(1.28 \mathrm{IU} / \mathrm{ml})$ and least by $30 \%(0.94 \mathrm{IU} / \mathrm{ml})$. The results indicate that moisture is an essential element for microbial growth (Figure-8).

\section{Incubation time}

The results indicated that $72 \mathrm{hrs}$ of incubation is the optimum time for L-asparaginase production. The reason for this can be dependent on the fungal strain used for the production of the enzyme (Figure-9).

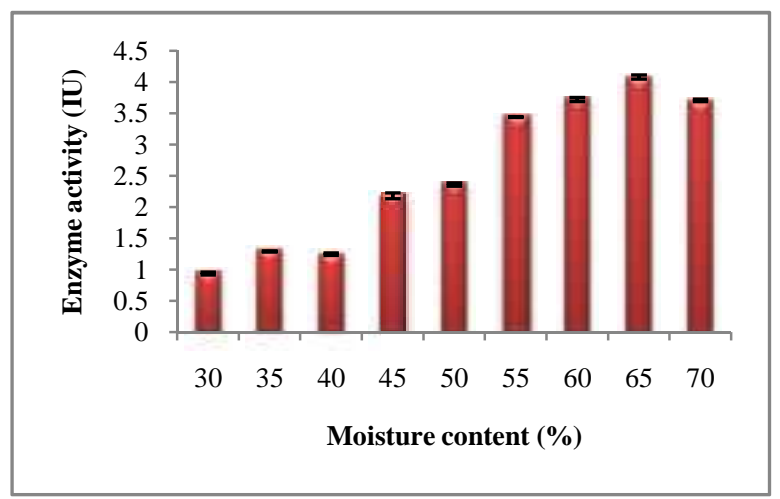

Fig. 8 Effect of initial moisture content on the activity of Lasparaginase

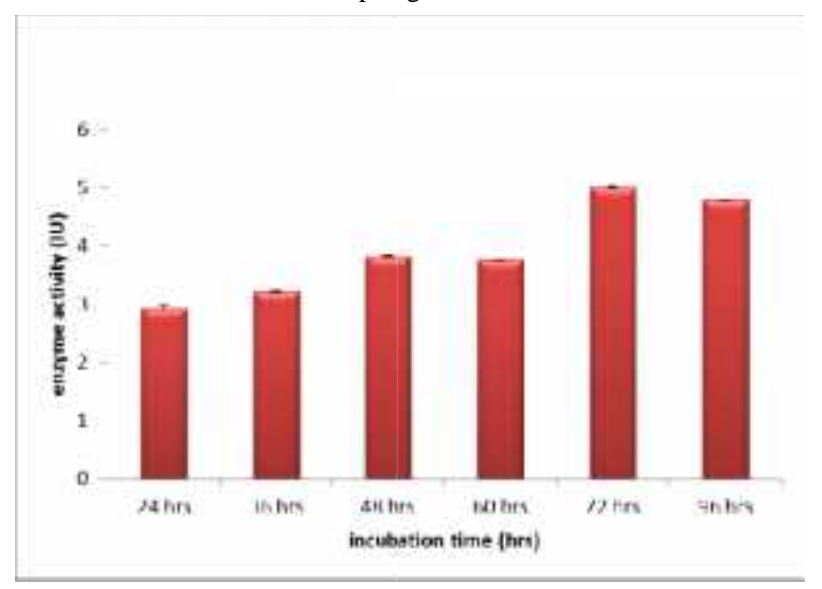

Fig. 9 Effect of incubation time on L-asparaginase activity

\section{Effect of nutritional parameters}

\section{Carbon sources}

Results indicated that $0.5 \%$ glucose was the optimum carbon source with $5.28 \mathrm{IU}$ of enzyme activity followed by fructose (4.84 IU) and sucrose (4.63 IU) (Figure-10). 


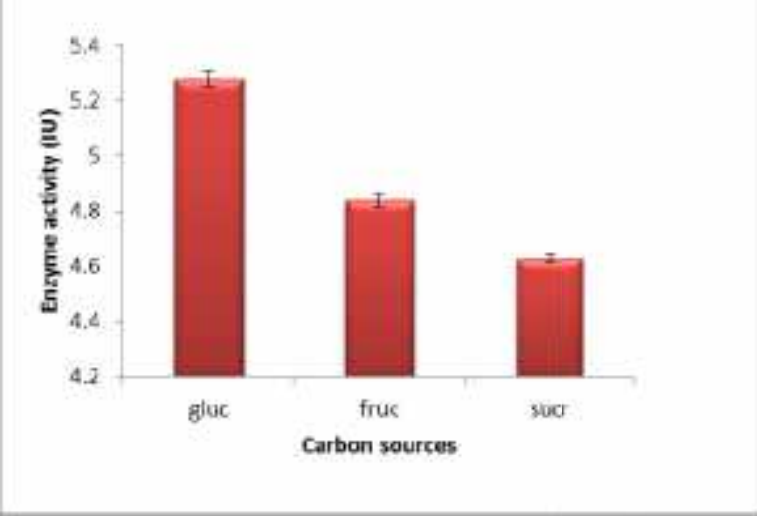

Fig. 10 Effect of various carbon sources on L-asparaginase activity

Similar results have been reported with $18.8 \mathrm{IU} / \mathrm{ml}$ of enzyme activity [30]. $0.4 \%$ glucose was chosen to be the best. Other reports show that $0.3 \%$ glucose $(6.92 \mathrm{IU} / \mathrm{ml})$ as the optimum glucose concentration (Palleum et al., 2011). Carbohydrates are generally used as sources of carbon in fermentation. Carbon sources enhance the growth of microorganism and also results in the increase of enzyme production. However the use of carbon sources for L-asparaginase production has been at two different ends. In case of $E$. coli $W$ and $E$. coli K12, glucose suppressed the growth whereas maximum production of L-asparaginase with glucose was also reported (Kumar et al., 2010).

\section{Nitrogen sources}

It was found that ammonium sulphate at $0.5 \%$ concentration showed the maximum enzyme activity (4.77 IU) followed by peptone (4.17 IU), ammonium nitrate (4.14 IU), yeast extract (3.91 IU), beef extract (3.83 IU) and least by ammonium chloride (3.36 IU) (Figure-11). Addition of nitrogen source with the substrate enhances enzyme activity (Chandrasekaran 1991). $3 \%$ ammonium sulphate was reported to be the optimum with 191.2 IU (Uppuluri et al., 2009). The present results are in agreement with the results where $0.5 \%$ ammonium sulphate showed 7.36 IU enzyme activity (DeAngeli et al., 1970).

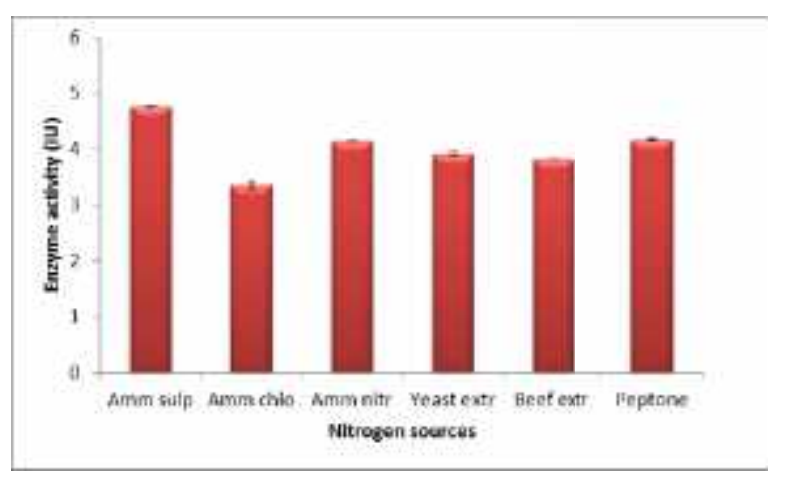

Fig. 11 Effect of various Nitrogen sources on L-asparaginase activity

\section{Phosphate sources}

Phosphate plays a key role in the regulation of enzymes. Organic phosphates show lower tolerance range than inorganic phosphate in secondary metabolic process (Kletzien et al., 1997). In the present investigation it was found that, dipotassium hydrogen phosphate with $0.5 \%$ was the ideal source of phosphate for the production of L-asparaginase
(Figure-12). The present results are similar to the results in which $0.5 \%$ of di potassium hydrogen phosphate is reported to be the optimum amount of phosphate requirement (Mukherjee et al., 2000). Further, the di potassium phosphate showed an enzyme activity of 5.01 IU and potassium di hydrogen phosphate showed the least activity (3.71 IU).

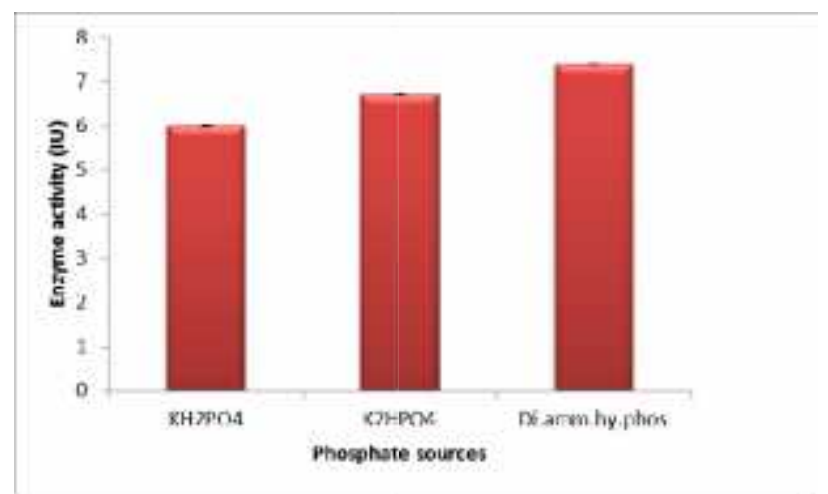

Fig. 12 Effect of various phosphate sources on L-asparaginase activity

\section{Metal ions}

Metal ions such as $\mathrm{Mg}, \mathrm{Mn}, \mathrm{Zn}, \mathrm{Cu}, \mathrm{Ca}, \mathrm{Na}$ and $\mathrm{Fe}$ are essential for cell mass formation and also they act as cofactors for several bio-synthetic enzymes (Schiffmann et al., 2005). In the present study it was found that $0.1 \%$ of manganese enhanced the L-asparaginase production followed by copper sulphate and zinc sulphate (4.11 IU) and least activity by magnesium sulphate (3.83 IU) (Figure-13). $10 \mathrm{~m}$ $\mathrm{mol} / \mathrm{l}$ of metal ions such as $\mathrm{Na}, \mathrm{K}, \mathrm{Mg}, \mathrm{Zn}, \mathrm{Ca}, \mathrm{Co}, \mathrm{Ba}$ and $\mathrm{Ni}$ are reported not to cause any inhibitory activity (Borkotakyet al., 2002). Present results are in contradiction to the results where copper is reported to act as co-factor (Robinson and Berk. 1969). Supplementation of $0.001 \%$ of Copper, Zinc and manganese enhances enzyme activity.

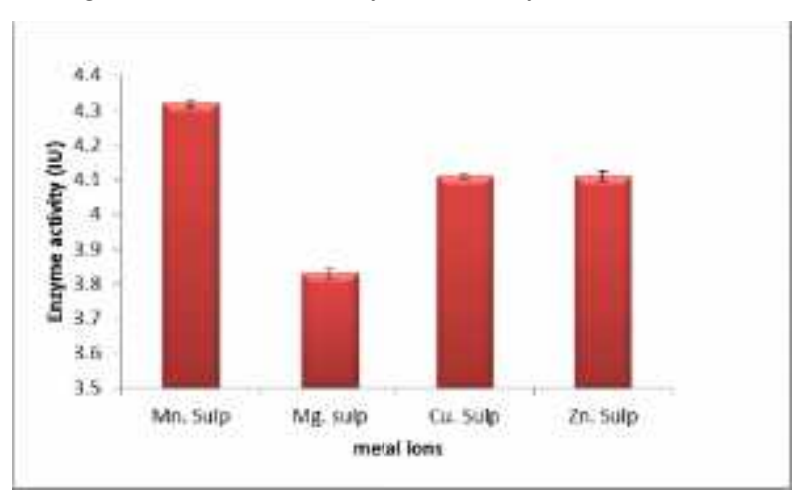

Fig. 13 Effect of various metal ions on L-asparaginase production

\section{CONCLUSION}

The present study includes the physical and nutritional parameters which majorly affect the production of Lasparaginase. It can be shown that keeping all the parameters in regard, the production of L-asparaginase can be enhanced and as fungal L-asparaginase is gaining the attention of researchers; this process optimization can provide a reference for the mass production. From the experimental results of the present study it was concluded that, the soil isolate Aspergillus tamarii BBKNM3 strain derived a sign that, Lasparaginase production was dependent on the temperature and $\mathrm{pH}$. The outcomes have also provided new information on how the isolated fungal strain is capable to produce the 
extracellular enzyme and the productivity of the enzyme was increased in the solid state fermentation with rice bran as substrate. Moreover, optimization of enzyme production by using different source was found to be ideal way for high enzyme yield.The future perspective of the present study aims at the mass production of L-asparaginase and also for the insight to its other medical applications.

\section{Acknowledgements}

The authors are thankful to the Department of Biotechnology (DBT), Ministry of Science and Technology, Government of India, New Delhi, for funding the Bioinformatics Infrastructure Facility Project (BT/BI/25/001/2006 VOL II date 05-03-2012), The Interdisciplinary Program for Life Science Project (BT/PR/4555/INF/22/126/2010 dated 30-092010), UGC-UPE fellowship and P. G Department of Biotechnology and Microbiology, Karnatak University, Dharwad, for providing the necessary facilities for the research.

\section{Competing Interests}

The authors declare that they have no competing interests.

\section{Statistical Analysis}

All the experimental data were carried in triplicates and expressed as means \pm standard errors. The statistical analyses of the data were performed using one way ANNOVA variance SPSS version 20.0 software with advanced models (SPSS Japan, Tokyo, Japan). Differences between means were located using Tukey's test $(P<0.05)$.

\section{References}

Ali SS (1994) A fungal L-asparaginase with potential antitumor activity. Indian Journal of Microbiology 34, 73-76.

Amena S, Vishalakshi N, Prabhakar M, Dayanand A, Lingappa K. (2010). Brazilian Journal of Microbiology, 41, 173-178.

Borkotaky B and Bezbereauh RL. (2002). Folia microbiol, 47(5), 473-476.

Carrizales V and Jaffe W (1986). Interscience, 11, 9-15. Chandrasekaran M, Lakshmanaperumalsamy P, Chandramohan D. (1991). Combined effect of environmental factors on spoilage bacteria. Fis Tech (India); 28: 146-153.

Curran MP, Daniel RM, Guy RG and Morgan HW. (1985). Arch Biochem Biophys, 241, 571- 576.

De-Angeli C, Pocciari F, Russi S, Tonolo A, Zurita VE, Ciaranf E and Perin A. (1970). Effect of Lasparaginase from Aspergillus terreus on ascites sarcoma in the rat, Nature, Vol. 225, pp. 549-550.

Drainas D and Drainas C. (1985) A conductometric method for assaying asparaginase activity in Aspergillus nidulans asparaginasens, Eur. J. Biochem., Vol. 151, pp. 591-593.

Dubois M, Gilles KA, Hamilton JK, Rebers PA and F Smith. (1956). Calorimetric method for determination of sugars and related substances. Anal. Chem. 28: 350356.

El-Bessoumy AA, Sarhan M, Mansour J. (2004). Production, isolation, and purification of Lasparaginase from Pseudomonas Aeruginosa 50071 using solid-state fermentation. J Biochem Mol Biol, 37: 387-393.

Gulati R, Saxena RK, Gupta RA. (1997). Rapid plate assay for screening LA producing micro-organisms. Lett Appl Microbiol 1997; 24: 23-26.

Gupta N, Dash J S, Basak CU (2009). L- asparaginases from fungi of Bhitarkanika mangrove ecosystem. As Pac J Mol Biol Biotechnol 17: 27-30.

Hosamani R and Kaliwal B. (2011). International Journal of Microbiology Research, 2, 108-119.

Imada A, Igarasi S, Nakahama K. and Isono M. (1973). Journal of General Microbiology, 76, 85-99.

Khamna S, Yokota A and Lumyong S. (2009), International Journal of Integrative Biology, 6(1), 2226.

Kletzien RF, Harris PK, Foellmi LA. (1994)The FASEB Journal vol 8, No 2, 174-181

Koneman EW, Allen SD, Janda WM, Schreckenberger PC, Winn WC (1977). Color Atlas and Textbook of Diagnostic Microbiology. (5th edn), J.B. Lippincott company, Philadelphia, USA.

Kumar S, Veeranki VD and Pakshirajan K. (2010) Assessment of Physical Process Conditions for Enhanced Production of Novel Glutaminase-Free LAsparaginase from Pectobacterium carotovorum MTCC 1428, Appl. Biochem. Biotechnol., DOI 10.1007/s12010-010- 9041-x.

Lapmak K, Lumyong S, Thongkuntha S, Wongputtisin P, Sarsud U (2010). L-asparaginase production by Bipolaris sp. BR438 isolated from brown rice in Thailand. Chiang Mai J Sci 37: 160-164.

Lee SY, Nakajima I, Ihara F, Kinoshita H and Nihira T. (2005) Cultivation of entomopathogenic fungi for the search of antibacterial compounds, Mycopathologia, Vol. 160, pp. 321-325.

Lowry OH, Rosenbrough NJ, Farr AL, Randall RJ. (1951). Protein measurement with Folin Phenol reagent. J Biol Chem 193, pp. 265-275.

Maladkar NK, Singh VK, Naik SR. (1993). Fermentative production and isolation of L-Asparaginase from Erwinia carotovora, EC-113. Hindustan Antibiot Bull 1993; 35:77-86.

Mashburn L and Wriston JC. (1964) Tumor inhibitory effect of L-asparaginase from Escherichia coli, Arch. Biochem. Biophys., Vol. 105, pp. 450-452.

Mishra A. (2006) Production of L-asparaginase, an anticancer agent, from Aspergillus niger using agricultural waste in solid state fermentation, Appl. Biochem. Biotechnol., Vol. 135, pp. 33-42.

Miura M, Hirano M, Kakizawa H, Morita A, Uetani T and Yamada K. (1970). Inhibitory effect of L-asparaginase in lymphocyte transformation induced by phytohemagglutinin, Cancer Res., Vol. 30, pp. 768772.

Mohapatra BR, Sani RK, Banerjee UC. (1995). Characterization of L-Asparaginase from Bacillus sp. Isolated from an intertidal marine alga (Sargassum sp.). Letteras in Applied Microbiology; 21:380-383.

Mukherjee J, Majumdar S. and Scheper T. (2000). Appl Microbiol. Biotechnol. 53, 180-184.

Narayana KJP, Kumar KG, Vijayalakshmi M. (2008). Indian Journal of Microbiology, 48, 331-336. 
Narta KU, Kanwar SS and Azmi W. (2007). Pharmacological and clinical evaluation of Lasparaginase in the treatment of leukemia, Crit. Rev. Oncology/Hematology, Vol. 61, pp. 208-221.

Pallem C, Nagarjun V, Srikanth M. (2011). Production of a tumour inhibitory enzyme, L-asparaginase through solid state fermentation using Fusarium oxysporum. Int J Pharma Sci Rev Res; 7(2): 189-192.

Pieters R, Hunger SP, Boos J, Rizzari C, Silverman L, Baruchel A, (2011) L-asparaginase treatment in acute lymphoblastic leukemia: a focus on Erwinia asparaginase. Cancer; 117(2):238-249.

Raha SK, Roy SK, Dey SK and Chakrabarty SL. (1990). Purification and properties of an L-asparaginase from Cylindrocarpon obtusisporum MB-10, Biochem. Int., Vol. 21, pp. 987-1000.

Reynolds D and Taylor JW. (1993). The Fungal Holomorph: A Consideration of Mitotic Meiotic and Pleomorphic Speciation, CAB International, Wallingford, UK.

Robinson SR. and Berk B. (1969). Biotech.Bioeng, 11, 1211.

Sarquis MI, Oliveira EM, Santos AS, and Costa GL, (2004). Production of L-asparaginase by filamentous fungi. Epub; 99 (5):489-92

Savitri, Asthana N, Azmi W (2003). Microbial Lasparaginase-A potent antitumor enzyme. Ind $J$ Biotechnol 2: 184-194.
Schiffmann R, Heine A, Klebe G and Klein Christain DP.(2005) Angewandte Chemie International Edition, 10.1002/anie.200500592.

Shaffer PM, Arst HN, Estberg L, Fernando L, Ly T and Sitter M. (1988). An asparaginase of Aspergillus nidulans is subject to oxygen repression in addition to nitrogen metabolite repression, Mol. Gen. Genet. Vol. 212, pp. 337-341.

Siddalingeshwara KG and Lingappa K. (2010) an International Journal of Pharmaceutical Sciences, 1(1), 103-112.

Sreenivasulu V, Jayaveera KN and Rao PM. (2009b). Optimization of process parameters for the production of L-asparaginase from an isolated fungus, Research $J$. Pharmacognosy and Phytochemistry, Vol. 1, No.1, pp. 30-34.

Tamura K, Dudley J, Nei M, Kumar S (2007) MEGA 4: Molecular Evolutionary Genetics Analysis (MEGA) software version 4.0. Mol. Biol. Evol. 24:1596-1599.

Theantana T, Hyde KD and Lumyong A. (2007). Asparaginase production by endophytic fungi isolated from some Thai medicinal plants, KMITL Sci. Tech. J., Vol. 7 No. S1, pp. 13-18.

Uppuluri KB, Rami Reddy DS. (2009). Optimization of Lasparaginase Production by isolated Aspergillus niger using sesame cake in a Column Bioreactor. J P App Microb, 3(1): 83-90.

Verma NK, Kumar G, Kaur, Anand S, (2007). Lasparaginase: A promising chemotherapeutic agent. Crit. Rev. Biotechnol. 27: 45-62.

\section{Please cite this article in press as:}

Mahabal N. S and Kaliwal B. B (2017), Production of L-Asparaginase From Rhizosphere Soil Fungus Aspergillus Tamari, International Journal of Current Advanced Research, 6(3), pp. 2376-2383.

http://dx.doi.org/10.24327/ijcar.2017. 2383.0013 